Isotopes and Applications

Working Group: Report update

October 2013

M. A. Stoyer, J. J. Ressler, B. Sherrill, S. Lapi, G.

Peaslee, A. Couture, T. Chupp

November 5, 2013 
This document was prepared as an account of work sponsored by an agency of the United States government. Neither the United States government nor Lawrence Livermore National Security, LLC, nor any of their employees makes any warranty, expressed or implied, or assumes any legal liability or responsibility for the accuracy, completeness, or usefulness of any information, apparatus, product, or process disclosed, or represents that its use would not infringe privately owned rights. Reference herein to any specific commercial product, process, or service by trade name, trademark, manufacturer, or otherwise does not necessarily constitute or imply its endorsement, recommendation, or favoring by the United States government or Lawrence Livermore National Security, LLC. The views and opinions of authors expressed herein do not necessarily state or reflect those of the United States government or Lawrence Livermore National Security, LLC, and shall not be used for advertising or product endorsement purposes.

This work performed under the auspices of the U.S. Department of Energy by Lawrence Livermore National Laboratory under Contract DE-AC52-07NA27344. 


\section{Isotopes and Applications Working Group: Report update October 2013}

\section{(a) Any changes to the scientific program-Scientific Overview}

No significant changes are proposed for the scientific program. The standard mode of operation at FRIB will be to produce a rare isotope beam for a primary user, for example ${ }^{60} \mathrm{Ca}$ from a ${ }^{82} \mathrm{Se}$ beam. At the same time, the fragmentation or fission of the production beam will produce up to 1000 other isotopes that could be collected (harvested) and used for other experiments or applications. The potential applications of these harvested isotopes range from the determination of neutron cross sections for homeland security to kinetic studies of radionuclide uptake in biological processes. Longer-lived samples of the unused isotopes could be collected and used in an ion source for accelerated beam experiments at ReA3, ReA12 or other accelerator facilities outside FRIB.

Given these possibilities, the harvesting working group addresses two general areas:

- The potential uses of rare isotopes at FRIB that fall outside of basic research in nuclear physics, astrophysics, and particle physics

- The collection of selected isotopes that could be used to prepare radioactive targets or samples for experiments and allow a limited multi-user capability at FRIB.

A high-level overview of possible applications for isotopes produced at FRIB is given in the report Scientific Opportunities with a Rare-Isotope Facility in the United States written by the Rare Isotope Science Assessment Committee, National Research Council (National Academies Press, 2007) and in the RIA (now FRIB) Applications Workshop - see http://www.lanl.gov/orgs/t/workshop/homepage.htm. More details can be obtained from "Isotopes and Applications Working Group: Report update Feb. 2011".

The general areas of interest fall into 7 broad categories:

- Nuclear power (nuclear data is needed to optimize reactor design, safeguards applications, and for studies related to reprocessing or disposal of nuclear waste)

- Homeland security (nuclear data is needed for modeling of nuclear reactions, detection of nuclear material and other threats, and development and calibration of threat detection technologies)

- Stockpile stewardship (nuclear data is needed for modeling of nuclear reaction networks, similar to astrophysics studies, such as $(\mathrm{n}, 2 \mathrm{n}),(\mathrm{n}, \gamma),(\mathrm{n}, \mathrm{p})$, and $(\mathrm{n}, \mathrm{f}))$

- Medical diagnostics (development of new imaging and treatment technologies, kinetic studies of material uptake in the body, and the possible production of biomedical radioisotopes for diagnostics and therapy)

- Nanoprobes for materials science using radioisotopes (for example the use of polarized ${ }^{8} \mathrm{Li}$ )

- Fundamental symmetries, specifically the measurement of enhanced electric dipole moments of isotopes with significant octupole collectivity. The production and harvesting of ${ }^{225} \mathrm{Ra}$ and/or ${ }^{221 / 223} \mathrm{Rn}$ from the beam-dump water will produce 
significantly higher rates for ${ }^{232} \mathrm{Th}$ or ${ }^{238} \mathrm{U}$ than are anticipated at TRIUMF/ISAC (for $\mathrm{Rn}$ ) and from laboratory sources (for ${ }^{225} \mathrm{Ra}$ ).

- Industrial and environmental tracers (for example ${ }^{7} \mathrm{Be},{ }^{210} \mathrm{~Pb},{ }^{137} \mathrm{Cs}$, etc.)

\section{(b) Description of proposed experiment(s)}

Harvesting of isotopes could take place at various stages in the fragment separator, shown below.

Figure 1: Layout of the FRIB fragment separator area illustrating possible locations of isotope harvesting.

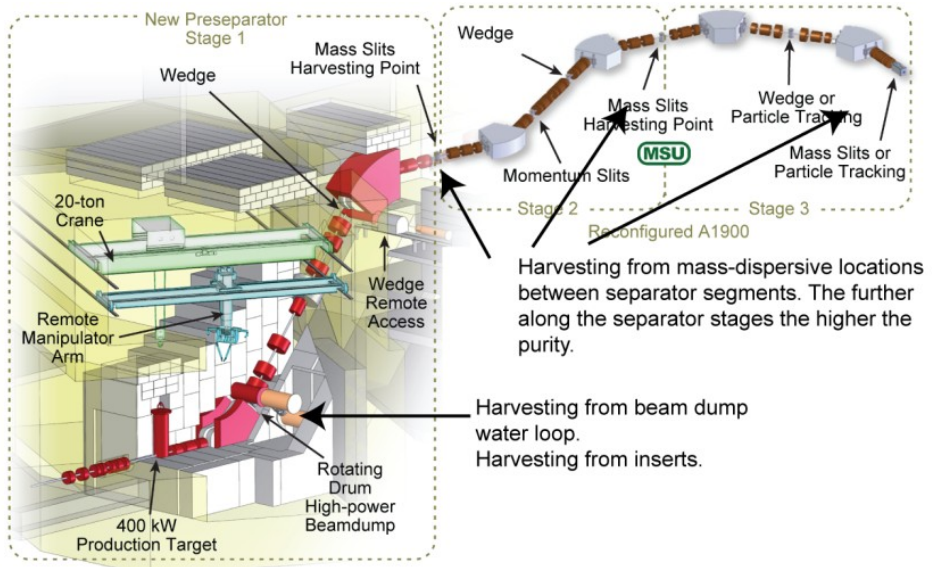

While a large number of isotopes may be available in the cooling water near the production target, the ions of interest may be overwhelmed by additional species. In addition, the cooling water from the beamline magnets has been initially designed to be on the same loop as the beam dump, further complicating separation. The Isotopes Harvesting Working Group has recommended that these lines be separate.

The separation of the cooling lines may allow collection of longer-lived species if the appropriate infrastructure is in place. For example, additional extraction columns may be placed on a secondary loop streaming a subset of the cooling water volume. These columns may be configured such that they may be replaced with relative ease; the removed columns may be transferred to a hot lab to collect the trapped ions. This collection scheme may work with longer-lived species, such as ${ }^{32} \mathrm{Si}\left(\mathrm{T}_{1 / 2}=160 \mathrm{y}\right)$ and ${ }^{44} \mathrm{Ti}\left(\mathrm{T}_{1 / 2}=11 \mathrm{y}\right)$.

The collection of isotopes may also take place at the mass slits along the FRIB separator. While these collection sites have the advantage of providing much cleaner separation, the production will be dependent upon the scientific program and the specific experiment being conducted. The ions may be embedded onto catcher foils, comprised of a "sandwich" of materials, similar to how isotopes are collected at the LANL isotope production facility. To limit contaminants, the beam tuning may be conducted on standard mass slits. These slits would then be exchanged for the collection slits for the production run. The exchange of mass slits would have to occur on a short time scale to minimize interference with the science program. Appropriate engineering of the operation, exchange and handling of the mass slits will have to be explored. Isotopes with intermediate half-lives (e.g. ${ }^{182} \mathrm{Ta}\left(\mathrm{T}_{1 / 2}=114 \mathrm{~d}\right)$ may be collected along the mass slits.

Isotopes may also be collected at the focus of the mass separator. These ions will have the least contaminants, and may be collected directly on a foil and used in a secondary experiment without further processing. Isotope collection in this manner is not parasitic, and will require the 
user to have the collection time bid for in a competitive process with experiments from the scientific program. For short-lived isotopes that are produced with high yields at FRIB, this may be the preferred collection scheme.

Finally one last idea surfaced during the group discussions at the second workshop for a potential radioisotope production site: namely using the secondary neutrons from the primary target and/or beam dump. FRIB will produce a significant flux $\left(\sim 10^{10} / \mathrm{cm}^{2} \mathrm{sec}\right)$ of high energy $(\sim 200 \mathrm{MeV})$ neutrons and one could consider the possibility of using these neutrons for isotope production and/or materials testing. This will require the ability to insert and retrieve targets materials (with and without a moderator) into the neutron beam near the carbon target and/or the beam dump. It was noted that something similar to this capability is already included in the planned facility. Post irradiation the targets/test materials will require transport in shielded casks to hot cells for processing and/or analysis. These may conducted in the same facilities planned for isotope harvesting from the beam dump.

Regardless of the collection scheme, a hot cell facility must be available for isotope harvesting. A modular facility has been discussed with FRIB staff, where users will provide a portable hot cell for use during a collection campaign. Upon conclusion of the collection period, the user will remove the hot cell and assorted items. The infrastructure to support the temporary hot cells, (e.g. crane, ventilation, rails) will be provided by FRIB. Initially, two such temporary hot cells may be supported with expansion plans for up to six cells.

\section{(c) Progress made since last report-current status}

There was a second isotope harvesting/applications workshop held at MSU July 23-24, 2012. More details can be obtained from "Proceedings: Second Workshop on Harvesting Radioisotopes from FRIB”, 2012.

Water cell harvesting end station was designed and constructed by Hope College and Washington Univ. St. Louis and tested at MSU.

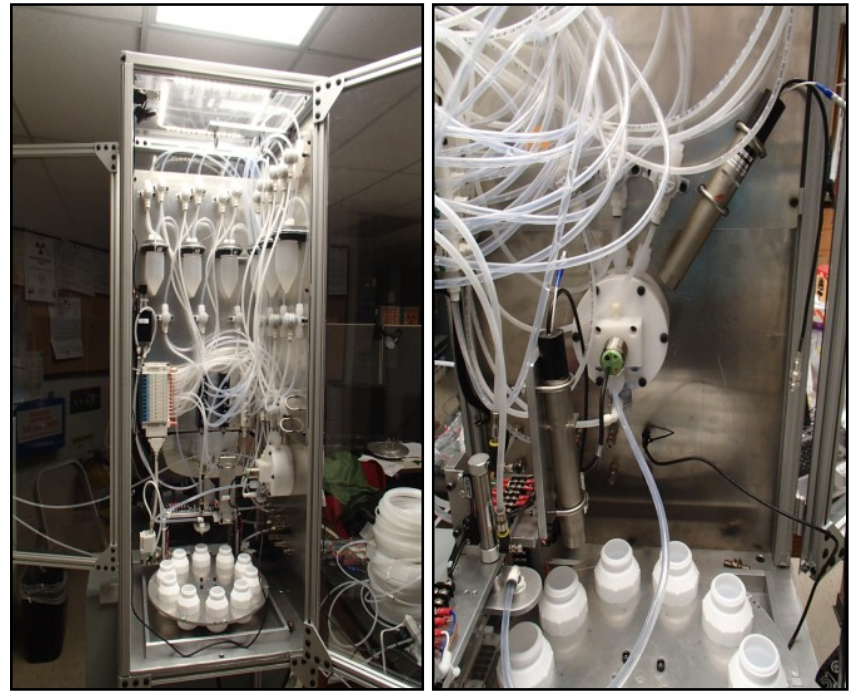

Fig. 2: The isotope harvesting end station designed to collect isotopes from the water dump currently used at MSU. 
Several successful test experiments were performed to collect ${ }^{24} \mathrm{Na}$ and ${ }^{67} \mathrm{Cu}$ from the water cell using the apparatus shown in Fig. 2. The collection efficiency of ${ }^{24} \mathrm{Na}$ from water samples sent to Hope College for quantification via gamma-ray counting was determined to be $\sim 50-55 \%$ in preliminary runs. In Aug. 2013, tests were conducted to harvest ${ }^{67} \mathrm{Cu}$. Some contaminations from reactions on water $\left({ }^{11} \mathrm{C}\right.$, $\left.{ }^{13} \mathrm{~N},{ }^{7} \mathrm{Be}\right)$ and the beam $\left({ }^{68} \mathrm{Zn}\right)$ were observed. However, separation chemistry successfully produced purified ${ }^{67} \mathrm{Cu}$ suitable for additional radioisotope test labeling chemical studies. Additional analysis is underway.

Priority isotopes were identified in the past and are shown in Table 1. A third workshop was scheduled for Oct. 14-16, 2013 at Washington Univ. St. Louis, but was postponed due to the government shutdown at the start of FY14 to a later as yet specified date. One item of discussion at the workshop is an update of the priority isotopes for harvesting. LLNL would like to add ${ }^{88} \mathrm{Zr}$ to the list to leverage developments for harvesting the medically important isotope ${ }^{89} \mathrm{Zr}$. Measurement of the ${ }^{88} \mathrm{Zr}(\mathrm{n}, \gamma){ }^{89} \mathrm{Zr}$ cross-section is important to SSP. Fundamental Symmetries would like to add ${ }^{221 / 223} \mathrm{Rn}$ to the table. There may be other cases where the list needs modification.

Table 1. Priority isotopes for harvesting at FRIB. These isotopes were identified at the Working Group meeting in Santa Fe, NM September 30 - October 1, 2010.

\begin{tabular}{|l|l|l|}
\hline $\begin{array}{l}\text { Isotope } \\
{ }^{32} \mathrm{Si}\end{array}$ & Half-life & Application \\
\hline${ }^{44} \mathrm{Ti}$ & $100 \mathrm{y}$ & Tracer; geology and botany \\
\hline${ }^{48} \mathrm{~V}$ & $16 \mathrm{~d}$ & Sedicine, astrophysics, nuclear structure \\
\hline${ }^{67} \mathrm{Cu}$ & $2.6 \mathrm{~d}$ & Medicine \\
\hline${ }^{85} \mathrm{Kr}$ & $10.0 \mathrm{y}$ & Astrophysics, stockpile stewardship \\
\hline $\mathrm{Eu} *$ & & Stockpile Stewardship \\
\hline${ }^{21 \mathrm{Rn}} \mathrm{Rn}$ & $14.6 \mathrm{~h}$ & Medicine \\
\hline${ }^{225} \mathrm{Ra}$ & $14.9 \mathrm{~d}$ & Medicine, Electric Dipole Moment \\
\hline${ }^{225} \mathrm{Ac}$ & $10.0 \mathrm{~d}$ & Medicine \\
\hline
\end{tabular}

*A range of Eu isotopes are of interest, A 147 - 154.

\section{(d) Near term activities and required resources and funding}

For each of the isotope harvesting scenarios described above, it was recommended that a single dedicated experimental radiochemical facility for harvesting, separation and characterization of the harvested material would be needed as part of FRIB to accommodate both internal as well as external users of the radioisotopes. Even for off-site usage of the harvested radioisotopes, a wetlab facility to characterize and package the radioisotopes for transport would be needed. Several suggestions made by the FRIB staff indicated additional space adjacent to the primary target facility that might be used, depending on the size of the radiochemistry lab and facilities required. Details of the suggested space and capabilities of this facility can be found in the "Proceedings: Second Workshop on Harvesting Radioisotopes from FRIB", 2012. 
Continued development of the harvesting end station is desired. Begin developments of harvesting from slits including simulations of expected production rates of targeted isotopes.

Hold third isotope harvesting/applications workshop (most likely in Spring 2014). 
(e) Collaboration list and organizational structure (if any):

Note: The current collaboration list is probably some subset of the attached, although there remains significant national and international interest in harvesting of isotopes.

\begin{tabular}{|l|l|l|}
\hline Initial 2010 Collaborators \\
\hline Ani & Aprahamian & $\begin{array}{l}\text { University of } \\
\text { Notre Dame }\end{array}$ \\
\hline Daniel & Bazin & MSU \\
\hline Sebastien & Bianchin & GSI \\
\hline Georg & Bollen & MSU \\
\hline Todd & Bredeweg & LANL \\
\hline Giovanni & Burgada & $\begin{array}{l}\text { CAEN } \\
\text { Technologies }\end{array}$ \\
\hline Xinfeng & Chen & $\begin{array}{l}\text { Washington } \\
\text { University }\end{array}$ \\
\hline Seonho & Choi & $\begin{array}{l}\text { Seoul National } \\
\text { University }\end{array}$ \\
\hline Jolie & Cizewski & $\begin{array}{l}\text { Rutgers } \\
\text { University }\end{array}$ \\
\hline Jason & Clark & ANL \\
\hline Daniel & Coupland & MSU \\
\hline Aaron & Couture & LANL \\
\hline Yves & Dardenne & LLNL \\
\hline Hugh & Evans & $\begin{array}{l}\text { Eckert \& } \\
\text { Ziegler }\end{array}$ \\
\hline Rafeael & Ferrer & MSU \\
\hline Don & Geesaman & ANL \\
\hline Amanda & Gehring & MSU \\
\hline John & Greene & ANL \\
\hline Marc & Hausmann & MSU \\
\hline Wen Chien & Hsi & $\begin{array}{l}\text { Procure } \\
\text { Treatment } \\
\text { Centers, Inc. }\end{array}$ \\
\hline Filip & Kondev & ANL \\
\hline Suzanna & Lapi & $\begin{array}{l}\text { Washington } \\
\text { University }\end{array}$ \\
\hline Steve & Libby & LLNL \\
\hline Sean & Liddick & MSU \\
\hline Milan & Matos & $\begin{array}{l}\text { Louisiana State } \\
\text { University }\end{array}$ \\
\hline Witold & Nazarewicz & $\begin{array}{l}\text { University of } \\
\text { Tennessee }\end{array}$ \\
\hline Jerry & Nolen & ANL \\
\hline
\end{tabular}




\begin{tabular}{|l|l|l|}
\hline Jorge & Pereira & MSU \\
\hline David & Radford & ORNL \\
\hline Andrew & Ratkiewicz & MSU \\
\hline Robert & Reba & $\begin{array}{l}\text { Georgetown } \\
\text { University } \\
\text { Hospital }\end{array}$ \\
\hline Jennifer Jo & Ressler & LLNL \\
\hline Lee & Riedinger & $\begin{array}{l}\text { University of } \\
\text { Tennessee }\end{array}$ \\
\hline Mark & Riley & $\begin{array}{l}\text { Florida State } \\
\text { University }\end{array}$ \\
\hline Ryan & Ringle & MSU \\
\hline Thomas & Ruth & TRIUMF \\
\hline Brad & Sherrill & MSU \\
\hline Karl & Smith & MSU \\
\hline Mark & Stoyer & LLNL \\
\hline Hiroyuki & Takeda & RIKEN \\
\hline Dave & Vieira & LANL \\
\hline Kathy & Walsh & MSU \\
\hline Ryan & Winkler & MSU \\
\hline Additional 2011 Collaborators \\
\hline Rene & Reifarth & GSI \\
\hline Roger & Henderson & LLNL \\
\hline Julie & Gostic & LLNL \\
\hline Graham & Peaslee & Hope College \\
\hline Francois & Nortier & LANL \\
\hline Tom & Ruth & TRIUMF \\
\hline \multicolumn{2}{|l|}{} \\
\hline
\end{tabular}

Workshop held July 23-24, 2012 at the Henry Conference Center, Michigan State University, E. Lansing:

List of participants:

Jill Berryman MSU

Georg Bollen MSU

Aaron Couture LANL

Heather Crawford LBNL

Cathy Cutler MURR

Jonathan D'Auria SFU

Joe Devore ORNL

Scott Essenmacher Hope

Doug Gage MSU 
Marc Hausman MSU

Alan Ketring MURR

Suzanne Lapi* Wash U.

Alain Lapierre MSU

Tara Mastren Wash U.

Milan Matos ORNL

David Morrissey* MSU

Meiring Nortier LANL

Graham Peaslee* Hope

Aranh Pen Hope

Dennis Phillips DOE

Reg Ronningen MSU

Brad Sherrill MSU

Suzanne Smith BNL

Dan Stracener ORNL

Andrew Wooten Wash U.

Nicholas Wozniak UNLV

Remco Zegers MSU

${ }^{*}$ Co-organizers 